\title{
Shop un á Son Gout
}

\author{
Arthur Asa Berger
}

Published online: 12 January 2011

(C) Springer Science+Business Media, LLC 2011

\begin{abstract}
An analysis of a number of books that deal with various aspects of shopping and marketing, offering insights into the way consumers are targeted by marketers and curious and fascinating aspects of consumer behavior.
\end{abstract}

Keywords Consumers · Consumer Cultures · Marketing · Retail Anthropology

There is probably no animal, with the exception of the laboratory rat, that is studied with such feverish attention as the human shopper-homo consumens. Paco Underhill relates in his book how he has shot 50,000 videos a year of people shopping, recorded numberless interviews with shoppers and collected countless "track sheets" of his employees surreptitiously following people and noting their every move as they wandered through various kinds of stores.

As I read his book and the others I'm dealing with in this roundup review, the words of H.G. Wells came to my mind. In The War of the Worlds, he wrote (and I'm taking some liberties with his words in places) "as men [and women] busied themselves about their various concerns, they were being scrutinized and studied, perhaps almost as narrowly as a man with a microscope scrutinizes the transient creatures that swarm and multiply in a drop of water." We can substitute shoppers for bugs in a drop of water without much stretching. Shortly after, Wells described the creatures that were studying us, and wrote "...Minds that are to our minds as ours are to the beasts that perish, intellects vast and cool and unsympathetic, regarded this earth's shoppers with envious eyes and slowly and surely drew their plans against them."

\footnotetext{
A. A. Berger $(\triangle)$

Broadcast and Electronic Communication Arts,

San Francisco State University,

1600 Holloway Avenue,

San Francisco, CA 94132, USA

e-mail: arthurasaberger@gmail.com
}

The intellectual abilities of the marketers and people in advertising agencies who work tirelessly to sell to us and of the people who wrote these books may not be of the same magnitude as the Martians and they may not be unsympathetic, but when you read these books you can see that marketers seem to know a great deal about all of us - and, more frightening, about each of us. Amazon.com lists 9,225 books on "shopping" and 34,625 on "selling." It has 93 books on consumer culture theory and 1,276 books on consumer cultures. The popularity of books on shopping, some of which become bestsellers, indicates that there is a great interest in shopping. Google lists 790,000,000 web sites involving "shopping." It has $244,000,000$ sites that deal with "buying," and 3,600,000 sites about "consumer culture in America."

Bridget Brennan's focus is on what motivates women to buy, as the title of her book, Why She Buys: The New Strategy for Reaching the World's Most Powerful Consumers, suggests. Women, she explains, are "the world's most powerful consumers," and Brennan offers considerable statistical evidence to support that contention. In her introduction, she writes that she will "analyze their propensity to buy, segment them by income bracket, target them by age group, deconstruct their search patterns, dissect their warranty card information, study their media habits" and discuss other related topics such as female socialization and the role that gender differences play in selling things to women. To flesh out her book she offers a number of case studies that show how important it is to recognize the role of gender in purchasing behavior.

She offers some statistics to back up her claim about the importance of women's purchases. Women make: $65 \%$ of apparel purchases; $52 \%$ of all new vehicle purchases; $45 \%$ of consumer electronics purchases; $80 \%$ of family health care decisions; $70 \%$ of all travel decisions; $55 \%$ of all wine purchases. It turns out that $20 \%$ of home purchases are 
made by single women. In addition, women influence $90 \%$ of all home purchases and $80 \%$ of all automobile purchases. The point is that women are major purchasers in all the most important consumer categories.

Brennan devotes considerable attention to the physical and psychological differences between men and women and offers tactical stratagems for reaching women and convincing them to purchase various products and services. She writes, "Don't lead with how something works-lead with the practical benefits; use stories to bring your service to life; leverage third party endorsements and testimonials." She also deals with contemporary social trends and their impact on consumption. She points out that since women are getting married later, they have more money to spend on themselves before they get married. The high rate of divorce also means "two of everything," to which she adds divorces "unleash a torrent of consumer spending."

The increasing number of older women is another market to be developed and because so many women all over the world work now, families generally have more disposable income. And though women have fewer children, they buy them more stuff. She has chapters that deal with "creating products with a female focus" and "the difference between sex appeal and gender appeal."

We find short case histories of products such as Lexus automobiles, The American Girl stores, and Callaway golf clubs ("engineered with female specific ergonomic adaptations"). In her case histories, Brennan focuses on how an understanding of women's psyches, bodies, and socialization patterns can be effective selling tools.

There is a bit of repetition in the book and it has a Johnny, or should it be Janey-One-Note quality about it, since just about everything is focused on selling products and services to women by understanding or perhaps exploiting their sensitivities and vulnerabilities. Although the author is a woman and focuses on women, her book is not by any means a feminist tract. Brennen is a marketer and her book was written for marketers so it doesn't make sense to criticize it for not being something else. The book has a number of interesting factoids and offers us an insight into how marketers think. Stylistically, Brennan writes in a style that seems to be a cross between a cookbook, a sex manual, and how-to-do-it book-which, in fact, describes the style found in many of these books.

Lee Eisenberg's book comes off as a jaunty exploration of shopping by someone interested in the phenomenon. $\mathrm{He}$ is a journalist (he was the editor-in-chief of Esquire and an executive vice president at Land's End) and approaches his subject much like an investigative reporter asked to investigate shopping. In the best tradition of investigative reporting, he interviews academics and other experts in marketing and related areas, does some field work on his own, and manages to incorporate, in a seemingly offhanded way, a considerable amount of scholarly research into shopping and consumer behavior.

He starts Shoptimism by discussing a little black dress that he wife bought, which, we are led to believe, got him interested in the topic. The first part of his book, "Them Versus You," deals with selling and all the forces involved with selling things that are marshaled against us, aided by consultants, in areas such as "bank check verification systems, ATMs, cash registers and currency handling systems; collection services systems; wireless data transmission systems; in-store communications systems; customerrelationship management systems" and so on and on.

He loves to make lists and offers piquant descriptions of various marketing gurus such as motivation researcher Ernest Dichter, who he describes as a balding, bow-tie-wearing, more jaunty-than-mad social scientist. In a section of the book titled Master Spy, Eisenberg describes Paco Underhill, author of Why We Buy: The Science of Shopping. as "the best-known retail snoop in the world." The second part of Eisenberg's book, "You Versus You," has chapters with jazzy titles such as "You Are What You Buy," "You Are Why You Buy," and "The Stop-Me-Before-I-Buy-Again Buyer," which are full of discussions of scholarly research. What Eisenberg does extremely well is sugar-coat the didactic pill of research findings by academics and insights from other shopping gurus with a veneer of smart-alecky titles. At the end of reading this book, you'll know a surprising amount about shopping as it relates to age, race, gender, Eisenberg's wife's taste in clothes and many other topics.

Trading Up argues that large numbers of consumers want luxury goods in many different categories and offers a hagiography of the creators of many brands of luxury goods purchased by people who are trading up. Authors Silverstein and Fiske argue that there are a large number of affluent people in the United States and other groups such as teenagers with a considerable amount of discretionary income (sometimes as much as $\$ 600$ a month) who "trade up." As they explain in their introduction to the paperback edition "There are 10 million households that take in more than $\$ 100,000$ each year. Trading-up spending accounted for about $21 \%$ of the $\$ 3.5$ trillion Americans spent in 2006 - some $\$ 730$ billion, up from $\$ 670$ billion the year before, in key New Luxury categories, including homes and home renovation, transportation, food and beverages, travel and entertainment, personal items, dining out, home goods and apparel and other fashion items."

New Luxury premium priced items are more expensive that ordinary ones in their category but not so expensive that they are out of reach, generally speaking, of upper-middle class people. These products provide, the authors claim, "higher levels of quality and taste" and stronger emotional appeals than ordinary products. One of the strongest groups to trade up is divorced people, who spend money to refashion their 
images and to salve their psychological distress. Since half of all marriages end in divorce, a lot of people are susceptible to the blandishments of New Luxury items. Also, many DINKS (double income, no kids) trade up, but it is women, especially single working women, who are the most important New Luxury consumers.

The authors discuss the situation in Japan, where five million or so single working women live with their parents and spend around $10 \%$ of their money on fashion items. These women (sometimes described as "parasite children," since they contribute no money to their families) are the largest spending segment in Japan and are also important tastemakers.

A considerable portion of the book is devoted to case histories that trace the histories of various products such as Sub-Zero and Viking home appliances, Panera restaurants, Trader Joe's, and Belvedere Gin. The study of the Callaway golf clubs is typical. The authors offer a short biography of Ely Callaway and discuss his innovative "Big Bertha" golf club, which they suggest, transformed the game of golf. An emotional engagement plays an important role in prompting golfers to pay $\$ 4,000$ (a thirteen times premium for Callaway clubs) for a Callaway outfit when they can purchase a similar set of clubs for less than $\$ 300$. What's interesting about the Callaway story is that he raised the price of a golf club and sold a large number of golf clubs; in so doing, he "shattered" the price-volume demand curve. In part, Callaway achieved his success because of the technological superiority of his clubs and because so many "brand apostles" for his clubs spread the word about them to others. The popularity of the "Big Bertha" and other Callaway clubs led to other manufacturers developing clubs that could compete with Callaway's clubs and consequently the production of high-end golf clubs exceeded the demand, so the category is now fairly static.

The book also discusses the Cheesecake factory, Kendall-Jackson wines, Victoria's Secret lingerie, "American Girl" stores, Starbucks coffee shop, BMWs and the decline of the Cadillac as a luxury car-aspirational brands that are part of American middle and upper-middle class life. You may not realize it, but if you buy a cup of coffee at Starbucks and drive there in a BMW or Mercedes or Lexus, you, too, have traded up.

Herb Sorenson's Inside the Mind of the Shopper: The Science of Retailing, uses observational research to analyze in-store shopping behavior. In his preface, he writes "The supermarket is my laboratory. After earning my Ph.D. in biochemistry and working for a brief period in the food industry, I traded a lab bench for the aisles of the supermarket." With the possible exception of Paco Underhill, no man has spent more time or intellectual energy than Sorenson trying to figure out what goes on in the minds of supermarket shoppers and working on ways to get shoppers to spend more money in supermarkets.
He discusses what we might call the "supermarket wars" as traditional supermarkets (think Safeway) are caught in a crossfire from gigantic megamarkets (think Walmart) and small "marketside" stores (think Trader Joe's and Tesco's "Fresh and Easy") that stock a limited number of items. Research, he points out, indicates that half of all shopping trips involve people purchasing five or fewer items (in every continent except Africa and Antarctica) and sixteen percent of shoppers purchase only one item. Given these statistics, making it easy for quick trip shoppers to find things in stores becomes crucial. It turns out that the average supermarket shopper buys only 300 to 400 "distinct" items in a typical year and only about half that many items on a regular basis. About 80 items (called "the big head") contribute to around $20 \%$ of typical stores sales, with milk and bananas being the two dominant items and 1,000 items ("the long tail") contributing about $50 \%$ of a store's sales.

The problem supermarkets face involves facilitating shoppers getting from one item on their list to the next as quickly as possible. This means that "seconds per dollar" becomes the crucial element in supermarket productivity. Sorenson deals with topics such as designing supermarkets, increasing shopper efficiency (getting shoppers from one item to the next as quickly as possible), enhancing supermarket perimeters, maximizing packaging, enhancing multi-cultural retailing, and increasing the role of the Internet in shopping. The book is data rich- full of charts and diagrams about different aspects of shopping. Sorensen probably spent more intellectual energy in studying supermarket behavior than Immanuel Kant expended in writing his Critique of Pure Reason. Sorensen offers an indepth and fascinating study of our behavior in a place that we all spend a considerable amount of time visiting every week and sometimes more often than that-our local supermarkets and their numerous competitors.

Paco Underhill is one of the best known researchers on consumer behavior. His book, Why We Buy: The Science of Shopping Updated and Revised for the Internet and Global Consumer and Beyond was a national bestseller. In his introduction, he suggests that this field might be considered a form of anthropology, studying the shopper in situ, and dealing with every aspect of shopping from parking lots to the actual behavior of shoppers to store design. He points out that many companies now employ anthropologists to investigate consumer behavior and notes that when he started studying consumer behavior, many of his academic colleagues accused him of selling out.

As mentioned earlier, Underhill has collected enormous amounts of data about every conceivable aspect of shopping in order to better understand how companies can reach and attract consumers and make it easier for them to purchase things. He videotaped people buying papers at a newsstand in Grand Central Station and noticed that the papers were 
arranged in a way that made it difficult for people to pick a paper up and purchase it, especially since most of them were carrying a briefcase or something else and had only one hand free. The papers were displayed at shin height which made grabbing one, generally with the left hand (since most people are right handed), very difficult. Purchasing a paper involved a number of steps that led to congestion around the newsstand, which meant that many people didn't buy one there. They got fed up with waiting and purchased a paper somewhere else. What the newsstand needed, Underhill writes, was a shelf at elbow height where people could rest their briefcases while finding money for the paper.

Underhill offers long discussions of strategic locations for placing shopping baskets in stores, of different zones found in stores, of why American shoppers automatically move to the right when shopping, of "capture rates" in supermarkets, and of the importance of impulse buying (60 to $70 \%$ of purchases in supermarkets were not planned). $\mathrm{He}$ also deals with category killers like Home Depot and Lowes, ways of making stores "user friendly," and many other topics related to a shopper's behavior. Underhill writes in a lively manner and offers all kinds of interesting facts. For example, he points out that "the average fouryear-old American child can identify more than one hundred brands" and that waiting time to purchase something is the most important aspect, in the minds of shoppers, about the service they received.

Buying In: What we Buy and Who We Are, by New York Times Magazine journalist Rob Walker (he writes a weekly column, "Consumed") contributes to the subtext found in all these books that our purchases, especially the brands of the things we buy, are both reflections and shapers of our personalities and identities. Walker coins a new word, "murketing," joining together the words "murky" and "marketing." Murky refers to "the increasingly sophisticated tactics of marketers to blur the line between branding channels and everyday life." The marketing part of the term involves people of all ages who are increasingly creating and participating in new kinds of marketing.

The book is divided into three parts: the desire code, marketing, and invisible bridges. In each of the parts Walker deals with various aspect of consumer behavior. $\mathrm{He}$ makes a distinction between rational behavior, which is based on reason, and rationale (as in rationalization) behavior, which is primarily based on emotions and is used by consumers to justify their purchases. He has many discussions, which we can consider short case histories, of the way products such as Red Bull, iPods, Pabst Blue Ribbon and all kinds of different T-shirt makers have marketed their products. Walker writes with a kind of bemused fascination at the role that buying and selling things plays in American culture and the changes that have taken place in branding and merchandising.
Gerald Zaltman's How Customer's Think: Essential Insights into the Mind of the Market, published by the Harvard Business School Press and written by an academic, is a scholarly analysis of marketing. Zaltman dedicates his book to the doctoral students, who, we can presume, will carry his work forward. In the preface to the book, he outlines what he will do. He will, among other things, examine the problems companies face in becoming customer-centric; explain a new marketing paradigm (marketing people love to talk about new paradigms) and demonstrate how companies applying the new paradigm have been successful; study the cognitive unconscious of consumers, which also involves neuroscience and neuromarketing; and consider the role of metaphor and memory in shaping consciousness and building brands.

Zaltman is a member of Harvard University's Mind, Brain, and Behavior Interfaculty Initiative, and his book devotes a good deal of attention to the way our minds work. His new paradigm, graphically represented in a diagram in the book, links the mind, the brain, the body, and society together; he argues they can't be studied independently of one another. He suggests that consumers have "core metaphors" that shape their thinking and writes "understanding these core metaphors can help marketers identify some of the most important but hidden drivers of consumer behavior." Zaltman devotes a considerable amount of attention to the role of the unconscious in shaping our behavior.

There is, he argues, a 95-5 split in our minds. He writes, "At least $95 \%$ of all cognition occurs below awareness in the shadows of the mind while, at most, $5 \%$ occurs in highorder consciousness." Then, adding a Freudian touch to his thinking, he explains, "the managerial tendency to focus on conscious consumer thought, while understandable and natural, also blocks managers' access to the world of unconscious human thought and feeling that drives most consumer behavior." This notion that unconscious imperatives shape our consumer behavior may explain why he doesn't think much of focus groups. Zaltman's book is a substantial scholarly work that offers numerous "bankable insights" (as one blurb writer put it) into the "mind" of customers and suggestions for marketing people on how to take advantage of the way customers think-or, perhaps it would be more accurate to say, most of the time don't think.

After reading these books, I find my mind is cluttered with all kinds of factoids on consumer behavior. I've also gained insights into the way marketers try to convince us to buy things and the way stores are designed to get us to buy things. One might ask - why would people buy books about shopping and selling? The answer is that we are all shoppers and as shoppers we are curious about every aspect of shopping, including how to be better shoppers. The books are all entertaining and interesting, but I came away 
from most of them thinking that their focus on the tactics of selling leaves them somewhat empty. That may be why you can read them, one after another. They are similar, in this respect, to the romance novels that people read-formulaic, with certain kinds of characters and situations, which we find interesting and appealing. Except that in romance novels we are reading about imaginary characters: English lords, beautiful damsels in distress, and nasty villains. In these buying and selling books, we are the main characters.

\section{Further Reading}

Brennan, B. 2009. Why she buys: The new strategy for reaching the world's most powerful consumers. New York: Crown Business.

Eisenberg, L. 2009. Shoptimism: Why the American consumer will keep on buying no matter what. New York: Free Press.
Silverstein, M. J., \& Fiske, N. 2003. Trading up: Why consumers want new luxury goods and how companies create them. New York: Portfolio.

Sorenson, H. 2009. Inside the mind of the shopper: The science of retailing. Upper Saddle River, NJ: Wharton School Publishing.

Underhill, P. 2009. Why we buy: The science of shopping. New York: Simon \& Schuster.

Walker, R. 2009. Buying in: What we buy and who we are. New York: Random House.

Zaltman, G. 2003. How customers think: Essential insights into the mind of the market. Boston, MA: Harvard Business School Press.

Arthur Asa Berger is Professor Emeritus of Broadcast and Electronic Communication Arts at San Francisco State University. He is the author of numerous articles and more than sixty books on media, popular culture, humor and tourism. Among his books are Ads, Fads and Consumer Culture (Rowman \& Littlefield), Shop 'Til You Drop: Consumer Behavior and American Culture (Rowman \& Littlefield), and The Objects of Affection: Semiotics and Consumer Culture (Palgrave/Macmillan). 